\title{
Ruptured hydatid cyst: A rare cause of anaphylaxis
}

\author{
Mustafa Erman Dörterler*1, Mehmet Emin Boleken ${ }^{1}$, Hasan Büyükaslan ${ }^{2}$ \\ ${ }^{1}$ Department of Pediatric Surgery, Harran University, Turkey \\ ${ }^{2}$ Depatrment of Emergency Clinic, Harran University, Turkey
}

Received: August 3, 2015

Accepted: September 14, 2015 Online Published: September 22, 2015

DOI: $10.5430 /$ css.v2n1p35

URL: http://dx.doi.org/10.5430/css.v2n1p35

\begin{abstract}
With hydatid cysts, although allergic reactions may occur with cyst rupture following anthelminthic treatment and percutaneous aspiration, it is rare for anaphylaxis to be associated with spontaneous cyst rupture of a liver hydatid cyst. The treatment of anaphylaxis follows the basic principles of emergency resuscitation. In regions where hydatid cysts are endemic, patients may present at the Emergency Department with clinical symptoms ranging from urticaria to anaphylaxis.
\end{abstract}

Key Words: Anaphylaxis, Hydatid cyst, Spontaneous rupture

\section{INTRODUCTION}

Liver hydatid cyst disease is generally asymptomatic, but sometimes symptoms may emerge as a result of extravasation of the cyst contents or pressure on neighboring tissues. ${ }^{[1]}$ Although allergic reactions may be seen with cyst rupture following anthelminthic treatment and percutaneous aspiration, it is rare for anaphylaxis to develop with spontaneous cyst rupture of a liver hydatid cyst. A hydatid cyst may rupture following trauma or spontaneously. ${ }^{[2]}$ Systemic anaphylactic reactions have been reported in $1.0 \%-12.5 \%$ of patients with intraperitoneal perforation and these reactions may be life-threatening. Hydatid cyst rupture requires emergency surgery. ${ }^{[3]}$ Here, we present an 8-year-old girl who presented to hospital with urticaria and respiratory complaints and was diagnosed with a ruptured hydatid cyst of the liver. This case report draws attention to the inclusion of hydatid cyst in the differential diagnosis of patients presenting with anaphylaxis.

\section{CASe presentation}

While playing in a park, an 8-year-old girl suddenly developed a rash and redness over her entire body and respiratory problems. She was taken to the nearest health center. Her general condition deteriorated and she required intubation and cardiopulmonary resuscitation. When the airway reflexes returned to normal after approximately 35 minutes, the patient was extubated and transferred to our faculty for further tests and treatment. After routine blood and biochemistry tests, brain, thorax, and abdominal computed tomography (CT) were performed.

In the Emergency Department, the patient's general condition was fair and she was pale and listless, with respiration at 36 breaths/min and rales in the right hemithorax on auscultation. The right upper abdominal quadrant was tender. The liver and spleen could not be palpated. An urticarial rash had spread over the skin. Laboratory testing revealed hemoglobin levels of $14.8 \mathrm{mg} / \mathrm{dl}$ and a white cell count of $29.17 / \mathrm{mm}^{3}$, with $80 \%$ polymorphonuclear cells and $5 \%$ eosinophils. The serum aspartate transaminase, alanine aminotransferase, and amylase were elevated slightly. CT revealed $7 \mathrm{~cm} \times 8 \mathrm{~cm}$ and $4 \mathrm{~cm} \times 3 \mathrm{~cm}$ hydatid cysts in the liver and a minimal amount of free fluid within the abdomen separated from the membrane (see Figure 1). Turkey.

Published by Sciedu Press 


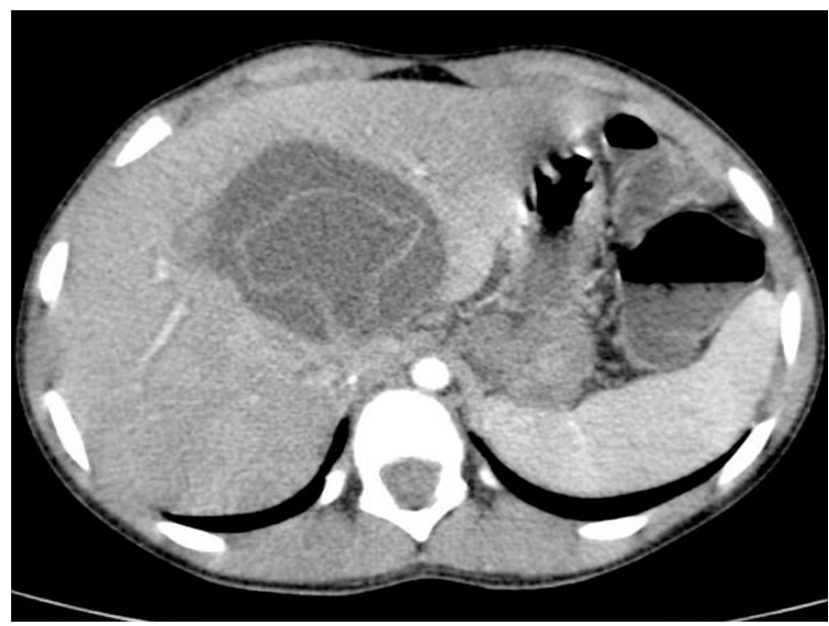

Figure 1. The ruptured hydatid cyst separated from the membrane

Postulating that the anaphylaxis was associated with hydatid cyst rupture, dexamethasone, prednisone, and chlorphenoxamine $\mathrm{HCl}$ were administered intravenously. When urticaria improved and hemodynamics stabilized, the patient was admitted to the pediatric surgical intensive care unit for close observation and monitoring. When her vital signs stabilized, she underwent a surgical partial cystectomy and omentopexy. The patient was treated with albendazole for 3 months postoperatively and no recurrence was observed.

\section{Discussion}

Hydatid cyst disease is an important parasitic disease seen in communities where agriculture and animal husbandry are widespread and environmental health and protective medical services are insufficient. In Turkey, the incidence of hydatid cyst disease is $2 / 100,000$ with a prevalence of $50 / 100,000 .^{[4]}$ Single-organ involvement is seen in $85 \%-90 \%$ of cystic echinococcosis cases, with a single cyst in $70 \%$. The organ affected most frequently is the liver, with pulmonary involvement in 10\%-30\% of cases, and spleen, kidney, orbit, heart, brain, or bones disease in $10 \% .^{[5]}$

Initially, liver hydatid cyst disease is asymptomatic and may remain silent for years. In most cases, cysts are noticed incidentally during a radiological examination. The size and location of the cyst play a role in symptom development. Echinococcal cysts always carry a risk of rupture and anaphylactic reaction. Cyst rupture may be spontaneous or due to trauma. ${ }^{[6]}$ When a hydatid cyst ruptures, it is known as a complicated cyst, and presentation varies with the nature of the rupture. ${ }^{[7]}$ Allergic reactions may be associated with cyst rupture following anthelminthic treatment or percutaneous aspiration. Histamine expression when mast cells are stimulated by parasite antigens results in urticaria, wheezing, and occasionally life-threatening anaphylaxis. ${ }^{[7-9]}$ In this case, anaphylaxis developed following spontaneous cyst rupture while playing.

Anaphylaxis treatment follows the basic principles of emergency resuscitation. The known activities of drugs on the underlying pathological mechanism and the clinical status are the basis for treatment. In regions where hydatid cyst is endemic, such as Turkey, patients may present at the Emergency Department with symptoms varying from urticaria to anaphylaxis.

\section{Conclusion}

In Turkey, hydatid cyst disease continues to be a major public health problem. Therefore, in patients with anaphylaxis of unknown cause, a ruptured hydatid cyst should be included in the differential diagnosis.

\section{REFERENCES}

[1] Gunay K, Taviloglu K, Berber E, et al. Traumatic rupture of hydatid cysts: a 12-year experience from an endemic region. J Trauma. 1999; 46: 164-167. PMid: 9932701. http://dx.doi.org/10.1097/0 0005373-199901000-00028

[2] Derici H, Tansug T, Reyhan E, et al. Acute intraperitoneal rupture of hydatid cysts. World J Surg. 2006; 30: 1879-1883; Discussion 1884-1885.

[3] Akcan A, Akyildiz H, Artis T, et al. Peritoneal perforation of liver hydatid cysts: clinical presentation, predisposing factors, and surgical outcome. World J Surg. 2007; 31: 1284-1291. PMid: 17464537. http://dx.doi.org/10.1007/s00268-007-9024-4

[4] Tatar D, Güneş E, Berktaş Ö, et al. Akciğer kist hidatiği tanılı çocuk olgularımız. Akciğer Arşivi. 2003; 4: 31-5.
[5] Morar R, Feldman C. Pulmonary echinococcosis. Eur Respir J. 2003; 21: 1069-77. PMid: 12797504. http://dx.doi.org/10.1183/0 9031936.03 .00108403

[6] Aribas OK, Kanat F, Gormus N, et al. Pleural complications of hydatid disease. J Thorac Cardiovasc Surg. 2002; 123: 492-7. PMid: 11882820. http://dx.doi.org/10.1067/mtc. 2002.119341

[7] Kuzucu A, Soysal O, Ozgel M, et al. Complicated hydatid cysts of the lung: clinical and therapeutic issues. Ann Thorac Surg. 2004; 77: 1200-4. PMid: 15063234 . http://dx.doi.org/10.1016/j.ath oracsur.2003.09.046

[8] Yüceyar L, Demirok M, Özdilmaç İ, et al. Akciğer kist hidatiği nedeniyle torakotomi uygulanan hastada anafilaksi. Solunum. 2004; 6 : 235-8.

[9] Teoh L, Kerrigan A, May M, et al. Pseudo food allergy. Pediatr Child Health. 2005; 41: 63-4. PMid: 15670228. http://dx.doi.org/1 $0.1111 / j .1440-1754.2005 .00539 . x$ 